\title{
INFLUENCE OF POTASSIUM LEVELS AND SOME ANTI-SALINITY MATERIALS ON SWEET PEPPER GROWN IN SANDY SOIL AND IRRIGATION WITH HIGH SALINTY WATER UNDER NORTH SINAI CONDITIONS
}

\author{
S.A.A Abuo El-kasem \\ Veg. Res. Dept., Hort. Res. Inst., Agric. Res. Center, Agric. Res. Station, El-Arish, North Sinai, \\ Ministry of Agric. \&Soil Reclam., Cairo, Egypt.
}

Received: Jul. 18, 2017

Accepted: Aug. 7, 2017

\begin{abstract}
ABSTRAC: The present work was carried out during the two successive seasons of 2013 and 2014 at the Agriculture Research Station of Hortic. Dept., Agric. Res. Center, in El- Arish, North Sinai Governorate, Egypt. Sweet Pepper (Capsicum annum L.) Local hybrid "Fares" was used in this study. The objective of the experiments was to study the effect of four potassium rates i.e., 200 (K1)/fed., 250 (K2)/fed., 300 (K3)/fed., and 350 (K4)Kg/fed. from potassium sulfate $48 \%)$ with four treatments of foliar spray by some anti-salinity using $\left(1 \mathrm{~g} / \mathrm{l}^{-1} \mathrm{Zinc}, 5 \mathrm{~cm} / \mathrm{l}^{-1}\right.$ Humic acid, and $0.5 \mathrm{~g}^{-1} \mathrm{l}^{-1}$ Salicylic acid, and beside the control) under sandy soil which irrigated with high salinity water and saline water irrigation in North Sinai, on the growth, yield and some chemical contents in leaves and fruits of pepper plants as well as fruit quality. Split plot design was used in the experiment. The results showed that all growth parameters, gave the highest values with application of potassium level at the rate of $350 \mathrm{Kg}$ per fed. with foliar spray by any of Humic acid $5 \mathrm{~cm} / \mathrm{l}^{-1}$, Salicylic acid $0.5 \mathrm{~g} / \mathrm{l}^{-1}$, and $\mathrm{ZN} 1 \mathrm{~g} / \mathrm{l}^{-1}$, respectively as well as all fresh and dry weights of pepper plant organs expressed in roots, leaves, and stems, as well as clusters fresh weight and both total fresh and dry weight of pepper plants in the both seasons compared to application of potassium the other levels at (K1,K2 and K3) with any of foliar spray of (Zn, Humic and Salicylic acids). Application of the high potassium level (350 Kg per fed.) with the foliar spray by Humic acid, Zn, and Salicylic acid, showed a significant increase in marketable yield of fruit weight per plant (g), number of fruits per plant, average fruit weight as well as total yield per fed. in addition high potassium level (K4) with the foliar spray with any of salicylic acid, Humic acid and $\mathrm{Zn}$, respectively gave the low contents of $\mathrm{Na}^{+}$and proline in the leaves and fruits compared to the low levels of potassium in the both seasons. Application of potassium levels $\mathrm{K} 4$ or $\mathrm{K} 3$ with spraying by $\mathrm{Zn}$, Humic acid and salicylic acid gave the highest values for V.C content and T.S.S in sweet pepper fruits.
\end{abstract}

Key words: Sweet pepper, Potassium levels- foliar spray with some anti-salinity treatmentsunder sandy soil

\section{INTRODUCTION}

Pepper (Capsicum annum L.) is one of most popular and favorite vegetable crop cultivated in Egypt. Pepper are an important agricultural crop, not only for their economic importance but also for the nutritional value of its fruits, mainly because it is an excellent source of natural pigments and antioxidant compounds in addition to their excellent flavor and pungency Navarro et al. (2002). Pepper is very rich in vitamin C, B and B6 and pro-vitamin A. Moreover it is very high in $\mathrm{N}, \mathrm{P}$, and $\mathrm{K}$ and contains high amounts from magnesium and iron Sparky (2006). The Chilies and Pepper are cultivated in Egypt as annual production of about 601289 tonnes according to Statistics of 2014 season FAO (2016).

Water quality is a major constraint for crop production in the North Sinai region, as well as the fruit yield with dependence on the water quality. The underground water is 
the main irrigation source under drip irrigation system and most of irrigation water characterized with high salinity. Most of North Sinai locations which are exposed to combinations of environmental stress conditions, including low water quality, temperature fluctuations, and high irradiance. Also, most soils have low water holding capacity and low soil organic matter content. Under the condition of these reigns the water is the major limiting factor for plant growth. The environmental stress conditions may lead to reduce plant growth by affecting various physiological and biochemical processes, such as photosynthesis, respiration, translocation, ion uptake, carbohydrates, nutrient metabolism and growth promoters Jalleel et al. (2008).

The salinity causes some types of stresses in plants: osmotic, ionic, and oxidative. $\mathrm{NaCl}$, causes stresses such as reduce absorption and induce a massive efflux of water and $\left(\mathrm{K}^{+}\right)$ions in plant cells, resulting in water and nutritional imbalances. The accumulation of $\mathrm{Na}^{+}$to toxic concentrations and the production of reactive oxygen species (ROS) reduce the growth, yield, and production of economically important crops, such as cereals and vegetables (Bojórquez-Quintal et al., 2012; Munns and Tester, 2008).

Many investigators studied the responses of plants to application of Potassium in the soil and foliar spray with Zinc, Hmic and salicylic acid for tolerating stress. Concerning to known that it is not constituent of any plant structures or organs, but it plays potassium effect part in many it is an important regulatory roles in the plant; i.e., osmo-regulation process, regulation of plant stomata and water use, translocation of sugars and formation of carbohydrates, energy status of the plant, the regulation of enzyme activities, protein synthesis and many other processes needed to sustain plant growth and reproduction Hsiao and Luchli (1986). It is a highly mobile element in the plant and has a specific phenomenon, it is called luxury consumption. In addition, it plays a very important role in plant tolerance of biotic and abiotic stresses (Marschner., 1995).

The regulation of $\mathrm{K}^{+}$homeostasis is essential for plant adaptation to biotic and abiotic stresses. This adaptation is associated with the wide range of functions in which $\mathrm{K}^{+}$participates Shabala and Pottosin (2014). Recently it found that, $\mathrm{K}^{+}$ retention in the cells of roots and leaves has been identified as an important trait for salt tolerance. A strong negative correlation between the magnitude of salt-induced $\mathrm{K}^{+}$ loss and salt tolerance, observed in various crop species, suggested $\mathrm{K}^{+}$retention as a selection criterion between salt tolerant and sensitive varieties (Lin Duo and Danfeng 2003; Wu et al., 2013).

Concerning to the role of Zinc several investigators reported that Zinc $(Z n)$ is closely involved in a wide range of cellular processes, such as free radical defense, electron transport, protein and auxin biosynthesis, cell proliferation, and reproduction in plants. The $\mathrm{Zn}$ plays very important role in plant metabolism by influencing the activities of hydrogenase and carbonic anhydrase, stabilization of ribosomal fractions and synthesis of cytochrome Tisdale et al. (1984). It was found that, to induce tolerance to environmental stress conditions adding high amounts from $\mathrm{Zn}$ to regulate and maintain the expression of genes needed to protect cells from the detrimental effects of stress Cakmak (2005). Also, $\mathrm{Zn}$ is an essential micronutrient for all organisms and serves as a cofactor for more than 300 enzymes Gonzalez-Guerrero et al. (2005). In addition, Sawan, et al. (2002) found that $\mathrm{Zn}$ is required in the synthesis of tryptophan, which is a precursor in the synthesis of indole-3-acetic acid; hormone that it is inhibits abscission of squares and bolls. Zinc is an essential micronutrient and has particular physiological functions in all living systems, such as the maintenance of 
structural and functional integrity of biological membranes and facilitation of protein synthesis and gene expression. Among all metals, $\mathrm{Zn}$ is needed by the largest number of proteins. Zinc binding proteins make up nearly $10 \%$ of the proteomes in eukaryotic cells, and $36 \%$ of the eukaryotic Zn-proteins are involved in gene expression Andreini et al. (2006).

Regarding to humic acid substance which it contributing indirect and direct effects on plant growth. Indirect effects are through enrichment in soil nutrients, increase biological activities of microorganisms and higher cation exchange capacity (CEC), improvement of soil structure; whereas direct effects are various biochemical actions exerted on the cell wall, membrane or cytoplasm and mainly of a hormonal nature Cheny (2004). The hormone like activities of HA are well documented in various papers, in particular auxin, cytokinin and gibberellin like effects on the other hand, directly affect the processes associated with the uptake and transport of humic substances into the plant tissues Nardi et al. (2002). Several studies showed that the application of the Humic substance under water stress increased leaf water retention, increases the water holding capacity of the soil and the photosynthetic as well as antioxidant, positive influence on quantitative and qualitative traits of pepper plants Ameri and Tehranifar, (2012).

Recently, it is found that, salicylic acid acts as a potential non-enzymatic antioxidant as much as plant growth regulator, playing an important role in regulating a many plant physiological processes. SA has been identified as a signaling component in numerous plant responses to stress, including UV-B, exposure to ozone and pathogen attack. SA is also involved in the activation of the stress induced antioxidant system stimulates flowering in many plants, increase flower life, control ion uptake by roots and stomata conductivity Muthulakshmi et al (2017).
The objective of this work was to study the effect of potassium levels as soil application and some anti-salinity treatments i.e. foliar spray with ( $\mathrm{Zn}$, Humic, and SA) on sweet pepper production under saline irrigation water and sandy soil conditions in Northern Sinai.

\section{MATERIALS AND METHODS}

The present work was carried out during the two successive seasons of 2013 and 2014 at the Agriculture Research Station of Hortic. Dept., Agric. Res. Center, in ElArish, North Sinai Governorate, Egypt. Sweet Pepper (Capsicum annum L.) Local hybrid "Fares" was used in this study. The seeds were sown on $15^{\text {th }}$ April in the nursery in both seasons. Uniform Seedlings were selected and transplanted on $5^{\text {th }}$ and $10^{\text {th }}$ Jun in 2013 and 2014 seasons, respectively. Seedlings were transplanted besides drippier lines, the distance between every two drippier lines in each row were $100 \mathrm{~cm}$. The distance between plants in the same line was $40 \mathrm{~cm}$. The plot area was $12 \mathrm{~m}^{2}(12$ $\mathrm{m}$ long and $100 \mathrm{~cm}$ between each two dripper lines in each row).

The drip irrigation system was followed and the other normal cultural practices were used according to the recommendations of Ministry of Agriculture. for fertilizing pepper plants without adding potassium fertilizer, which it using it in several rates as the main treatment in the experiment.

The objective of this study was objective to study the effect of four potassium rates, i.e. $200 \mathrm{Kg}(\mathrm{K} 1), 250 \mathrm{Kg}(\mathrm{K} 2), 300 \mathrm{Kg}$ (K3) and $350 \mathrm{Kg}$ (K4) from potassium sulfate $48 \% \mathrm{~K}_{2} \mathrm{O}$ with four treatments of foliar spray of anti-salinity using (Zinc $1 \mathrm{~g} / \mathrm{I}^{-1}$ "Global Chelated Zinc $14 \% "$, Humic acid $5 \mathrm{~cm} / \mathrm{l}^{-1}$, Its contents include "Humic acid 18\%, Fulvic acid 14\%, Amino acid 19.93\%, Nitrogen 4.03\%, $\mathrm{P}_{2} \mathrm{O}_{5}$ 0.3\%, $\mathrm{K}_{2} \mathrm{O} 3.72 \%$, Zn 0.1\%, Fe $380 \mathrm{mg} \mathrm{l}^{-1}, \mathrm{Mn} 29.1 \mathrm{Mg} \mathrm{l}^{-1}$ and Cu $17 \mathrm{mg} \mathrm{l}^{-1 "}$, Salicylic acid $0.5 \mathrm{~g} / \mathrm{I}^{-1}$, and control which used its as the recommendation of the ministry). 
The treatments were arranged randomly in a split-plot design, in three replications, where the four potassium levels were randomly arranged in the main plots which it added thought 4 times, i.e. $25 \%$ of the different levels were added at four stages, the first during soil preparation, the second after one month from transplanting, the third at the flowering and the beginning fruit setting stage, the fourth at fruiting stage. Foliar spraying of treatments (Zinc, Humic acid, Salicylic acid, beside the control), were randomly distributed in the sub plots. Foliar spraying took place after 20,40, 60 and 80 days from transplanting

Some physical and chemical properties of the experimental soil and chemical analysis of irrigation water were presented in Tables 1 and 2, respectively, (According to Ryan et al., 1999).

\section{The following Data were recorded:}

\section{Vegetative growth}

A random sample of 5 plants from each sub plot was taken at 90 days after transplanting and the following vegetative characters were recorded: fresh weight of roots, stems, leaves, clusters (g), and dry weight of roots, stems, as well as leaves (g), and total fresh and dry weight/plant (g).

\section{Yield and its components}

Yield was divided into two grades (Marketable yield and unmarketable yield). The following measurements were studied: number of fruits per plant, average fruit weight (g). Fruits weight per plant $(\mathrm{g})$, yield per fed. for marketable yield (ton/fed.) as well as total yield per fed.

\section{Fruit quality}

At the green ripe stage (the marketable stage or edible stage) of the third picking samples of ten fruits were randomly taken from each sub plot and the following data were recorded:

\section{a. Ascorbic acid (V.C)}

It was determined in fruit juice (as $\mathrm{mg} / 100 \mathrm{ml}$ juice) using 2, 6 diclorophenol endophenol as described in A.O.A.C. (1990).

\section{b. $\mathbf{p H}$}

It was measured using $\mathrm{pH}$ meter A.O.A.C. (1990).

\section{c. Fruit total soluble solids (TSS \%) \\ It was measured using a hand} refractometer A.O.A.C. (1990).

Table 1: Mechanical and chemical properties of the experimental soil.

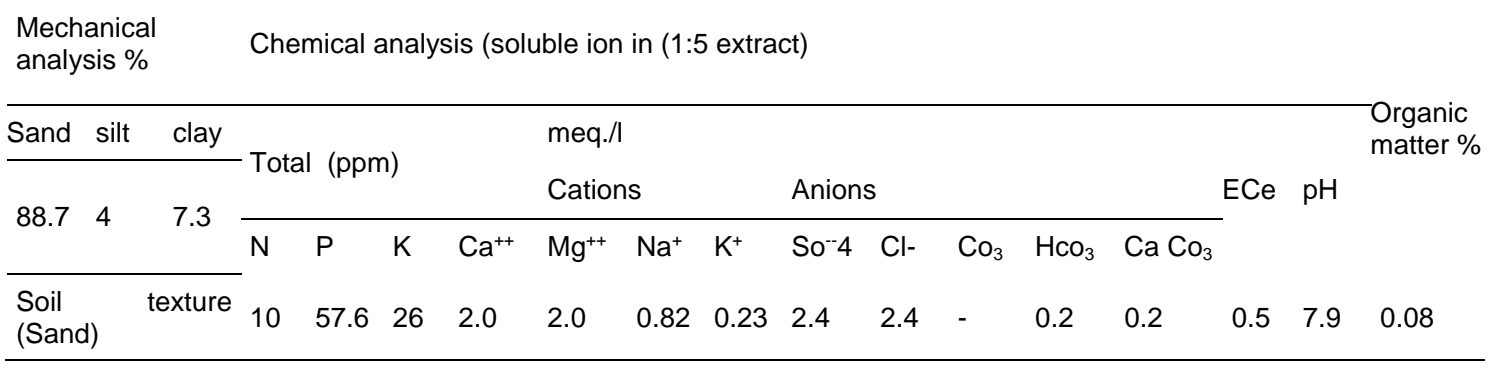

Table 2: Chemical analysis of irrigation water.

\begin{tabular}{|c|c|c|c|c|c|c|c|c|c|c|c|c|}
\hline \multirow{3}{*}{$\mathrm{pH}$} & \multirow{3}{*}{$\begin{array}{l}E C \\
\left(d S m^{-1}\right)\end{array}$} & \multicolumn{8}{|c|}{ Soluble ions(meq.1-1/L) } & \multirow{3}{*}{\multicolumn{2}{|c|}{ S.S.P\% S.A.R }} & \multirow{3}{*}{ R.S.C } \\
\hline & & \multicolumn{4}{|c|}{ Cations } & \multicolumn{4}{|c|}{ Anions } & & & \\
\hline & & $\mathrm{Ca}^{++}$ & $\mathrm{Mg}^{++}$ & $\mathrm{Na}^{+}$ & $\mathrm{K}^{+}$ & $\mathrm{Cl}^{-}$ & $\mathrm{HCO}_{3}^{-}$ & $\mathrm{CO}_{3}^{--}$ & $\mathrm{SO}_{4}^{--}$ & & & \\
\hline 7.86 & 8.28 & 15.4 & 14.6 & 45.2 & 0.2 & 47.5 & 2.6 & - & 25.93 & 12.9 & 64.3 & 25.7 \\
\hline
\end{tabular}




\section{Chemical continues of $N, P, K$, $\mathrm{Na}^{+}$and Proline in the leaves and fruits.}

a. Total nitrogen was determined using the method described by Bremner and Mulvancy (1982), b. Phosphorus content was determined using the method described by Ryan et. al. (1999), Potassium and Sodium contents were measured by flame photometer as described by Irri (1976), and c. Proline was determined spectrophotometrically following the ninhydrin method described by Bates et al. (1973).

\section{Statistical analysis}

Statistical analysis of the obtained data was carried out according to statistical analysis of variance according to Snedecor and Cochran (1980). Duncan's multiple range tests was used for comparison among the means (Duncan, 1958). The M stat C program was used for analysis.

\section{RESULTS AND DISCUSSION}

\section{Fresh and dry weight of pepper plant organs:}

\subsection{Effect of potassium fertilization levels}

Data in Table (3) show significant effects on most studied traits of fresh and dry weight of sweet pepper plants. except on leaves and clusters fresh weight in the both seasons. Potassium application level at 350 $\mathrm{Kg} / \mathrm{fed}$. gave the highest values in all fresh and dry weights of pepper plant organs expressed on roots, leaves, stems, as well as the clusters fresh weight, in the both seasons followed by the level at $300 \mathrm{~kg} / \mathrm{fed}$. The increment in fresh and dry weight of pepper plant organs may be due to the application of the high levels of potassium which induce enhancement and increase of root system efficiency which reflected to induce the growth and development of the roots. Potassium is related to the synthesis of proteins, carbohydrates, sugars and starch storage and this stimulated the growth, improved utilization of water and improve the resistance of the stress (Faquin, 1994). Many studies showed that the ability of plants to retain $\mathrm{K}^{+}$and to maintain $\mathrm{K}^{+} / \mathrm{Na}^{+}$ selectivity has been considered the key in the feature of salt tolerance (Tester and Davenport, 2003). Potassium deficient on crops causes grow slowly and have poorly developed root systems, Marco et al. (2011) on pepper plant, indicated that roots and shoots $\mathrm{K}^{+}$content were greater than $\mathrm{Na}^{+}$ content, suggesting that $\mathrm{K}^{+}$may act as the major monovalent cationic osmoregulator.

\subsection{Effect of foliar spray with anti- salinity treatments}

Data in Table (3) show that foliar spray with any of Zinc, humic acid or salicylic acid, induced significant effects on fresh and dry weight of different pepper plant organs more than the control in the both seasons except leaves, clusters and total plant fresh weight. The highest values, were obtained from the foliar spray with humic acid at rate of $5 \mathrm{~cm}$ per liter Foliar spray by using humic acid had a positive effect on plant growth, i.e. fresh and dry weight per plant. (Cheny, 2004; Nardi et al., 2002; and Varanin and Pinton, 2001) reported that the increasing in growth might be due to the effect of humic acid on biochemical actions exerted on the cell wall, membrane or cytoplasm which led to building and activities of hormones; i.e., auxin, cytokinin, and gibberellin like. Several studies showed that foliar spray with humic molecules under water stress gave an increase in photosynthetic, antioxidant metabolism and increased leaf water retention, consequently increased the plant growth of plant organs. (Fahram et al. 2014; Fu Jiu, 1995; and Nardi, 2002) 
Table 3: Effect of potassium fertilizer levels and foliar spray with some anti-salinity treatments on fresh and dry weight of pepper plants during 2013-2014 seasons.

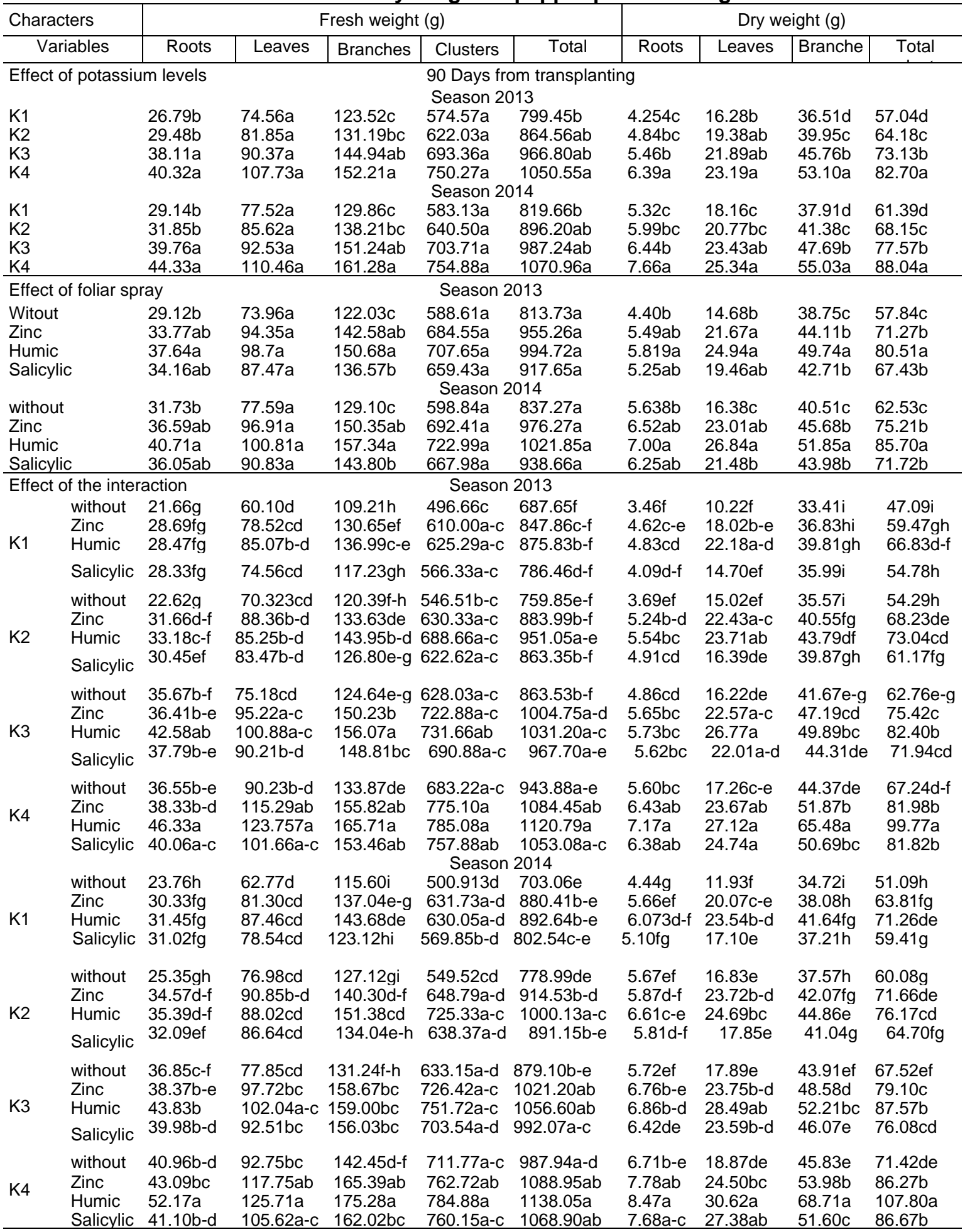

Values having the same alphabetical letter(s) did not significantly differ at 0.05 levels of significance, according to Duncan's multiple range test.

K1,K2,K3 and K4; Rates of potassium fertilization as follows: 200, 250, 300, and 350Kg per fed. Respectively. Application of foliar spray, i.e. Without spray, Zinc, Humic acid, and Salicylic acid., The spraying rates were as follows, $0.0,1.0 \mathrm{~g} / \mathrm{l}^{-1}, 5.0 \mathrm{~cm} / \mathrm{l}^{-1}$, and $0.5 \mathrm{~g} / \mathrm{l}^{-1}$, Respectively. 


\subsection{Effect of the interactions between potassium levels and foliar spray of anti-salinity treatments}

The results of the interactions between potassium levels and foliar spray by $\mathrm{Zn}$, Humic acid and Salicylic acid on fresh and dry weight of sweet pepper plants were presented in Table (3). The data show significant effects of the interaction between potassium application levels and foliar spray with $\mathrm{Zn}$, humic and Salicylic acids on most studied traits, i.e., fresh and dry weight of pepper plant. In general, the highest values of the previous characters were recorded with the highest potassium levels i.e. 350 $\mathrm{Kg} / \mathrm{fed}$. and foliar spray with Humic acid 5 $\mathrm{cm} / \mathrm{I}^{-1}$, followed by ZN $1 \mathrm{~g} / \mathrm{l}^{-1}$. These results may be due to the role of potassium element in metabolism and many processes needed to sustain and promote plant vegetative growth and development El-Bassiony et al. (2010 found that application of potassium sulfate at a rate of $200 \mathrm{~kg} / \mathrm{fed}$ presented the highest values of plant height, number of leaves, number of branches per plant and both of fresh and dry weights leaves of sweet pepper plants compared to the addition of $50 \mathrm{Kg}$ per fed., They reported also that K-humate application led to increasing and improving plant growth parameters. Application of K-humate had beneficial effects on nutrient uptake by plants and was particularly important for the transport and availability of micro nutrients which it is necessary for optimal plant growth and development. Moreover, many studies proved that the need for the $\mathrm{K}$ element to regulate some vital activities in many physiological and biochemical processes such as cell division, elongation, metabolism of carbohydrates and protein compounds, enzyme activation, photosynthesis, osmo-regulation, stomata movement, energy transfer, phloem transport, cation-anion balance and stress resistance (Karakurt et al., 2009; Zaky et al., 2006).

\section{Yield and its components \\ 2.1. Effect of potassium fertilization levels}

Data presented in Table (4) indicate that increasing potassium fertilization levels recorded the highest values on most studied traits of yield and its components. Application of potassium at a rate of $350 \mathrm{Kg}$ per fed. gave the highest values of marketable and unmarketable yield in both seasons followed by the level of $250 \mathrm{Kg}$ per fed. application of $350 \mathrm{Kg}$ per fed. of potassium sulfate gave the highest values of fruit weight per plant, number of fruits per plant and average fruit weight, as well as total yield (marketable yield + unmarketable yield per fed.), these results were observed in the first and the second seasons. The increment in total fruit yield may be due to the increase in number of fruits per plant and average fruit weight (Table 4) the promotion effect of $\mathrm{K}$ may be due to its role in enhancement accumulation of carbohydrates, proteins, activate of enzymes, activate and movement of mineral and stomata movement for water retention in branches and leaves as well as more tolerance of salt stress. These results confirm other reports on pepper plants, that number of fruit per plant and fruit size increased with the increasing of potassium levels and consequently increased both of the early and total yield (Bhuvaneswari et al., 2013; and Fawzy et al., 2005).

\subsection{Effect of foliar spray with anti- salinity treatments}

Data in Table (4) show significant effects of foliar spray with anti-salinity treatments on marketable yield traits, except, average fruit weight in the first season. Concerning unmarketable yield, data in the same table show significant effects for fruit weight in both seasons with highest values with spraying salicylic acid in both seasons; significant effects in the first season only for spraying treatments with the highest values with spraying of salicylic acid also; other traits had no significant effects in both 
season. Regarding to the total yield, data in the same table indicate significant effects by foliar spray treatments in both seasons except total marketable yield and total unmarketable yield in the second season, the highest total marketable yield and total yield (ton/fed.) were recorded with spraying humic acid, while the highest unmarketable yield was recorded with spraying salicylic acid or zinc in the first season. This result may be due to the material used in this experiment (Humic acid) which contain mixture compounds; i.e., Humic acid 18\%, Fulvic acid 14\%, Amino acid 19.93\%, Nitrogen $4.03 \%, \mathrm{P}_{2} \mathrm{O}_{5} 0.3 \%, \mathrm{~K}_{2} \mathrm{O} 3.72 \%, \mathrm{Zn}$ $0.1 \%$, Fe $380 \mathrm{mg} \mathrm{l}^{-1}, \mathrm{Mn} 29.1 \mathrm{Mg} \mathrm{l}^{-1}$ and $\mathrm{Cu}$ $17 \mathrm{~g} \mathrm{l}^{-1}$, These contents in the structure of the Humic acid contain some major elements, micro elements, organic acids and amino ribatonic on a high degree of availability for absorption by the plants, in addition to the natural composition makes them fixed and gave the requirements of plants for various physiological and biochemical processes. The increase in yield may due to that humic acids enhance the absorbance capacity of nutrients through the roots by having carboxyllic and phenolic groups and increasing $\mathrm{H}^{+}$-ATP as activity in the root cells Canellas et al. (2002). Also, Karakurt et al. (2009) reported that humic acid application affected pepper growth and fruit characteristics and had a positive influence on quantitative and qualitative traits of pepper plant. Increasing the rates of humic acid (1,2 and $3 \mathrm{ml} \mathrm{L}-1)$ increased pepper yield (quality and quantity) as compared with untreated plants (Abd ElRheem et al., 2012).

\subsection{Effect of the interaction between potassium levels and foliar spray with anti-salinity treatments}

Data in Table (4) show significant effects of the interaction between potassium fertilization levels and foliar spray on all studied traits, except the number of fruits per plant for unmarketable yield, total marketable and unmarketable yield (ton per fed.) in the second season. Application of potassium level (k4) with foliar spray by Humic acid recorded the highest values of marketable yield traits and total yield (total marketable + total unmarketable yield) in both seasons. The highest values of unmarketable fruit weight ( $g /$ plant) were recorded with the application of $200 \mathrm{Kg}$ potassium sulfate with foliar spray of Zinc. The highest values of unmarketable average fruit weight were recorded with the application of $300 \mathrm{Kg}$ potassium sulfate with spraying by zinc in the first season and by application of $300 \mathrm{Kg}$ potassium sulfate with spraying by humic acid in the second season. The increment in the total yield per fed. by the addition of the high level of potassium, i.e. $350 \mathrm{Kg}$ per fed. with humic acid at the rate of $5 \mathrm{~cm}$ per liter this might owe to the highest fruit weight and average fruit weight per plant and per fed. for marketable yield. Similar results were noticed on tomato by Padem and Ocal (1999) who demonstrated that increasing Khumate application dose led to a significant increase in fruit weight and total yield for tomato plant., In addition El-Bassiony et al. (2010) indicated that the highest total yield of sweet pepper plants was produced by using $200 \mathrm{~kg}$ per fed. from potassium sulfate, the highest values of fruit yield obtained when sweet pepper plants was sprayed with K-humate (4 gm/l-1) followed by potassium oxide $\left(4 \mathrm{~cm} / 1^{-1}\right)$.

\section{Chemical contents of pepper leaves and fruits.}

\subsection{Effect of potassium fertilization levels}

Data in Table (5) show significant effects for the application of potassium levels on most studied traits of sweet pepper plants in the both seasons, except, proline and $P$ content during the both seasons., data in the same table indicate that the application of potassium level (K4) recorded the highest values of the $N, P$ and $K$ in both leaves and fruits. Application of potassium level (K4) recorded the lowest values for $\mathrm{Na}^{+}$and 
Table 4: Effect of potassium fertilizer levels and foliar spray with some anti-salinity treatments on yield and its components of pepper plants during 2013-2014 seasons

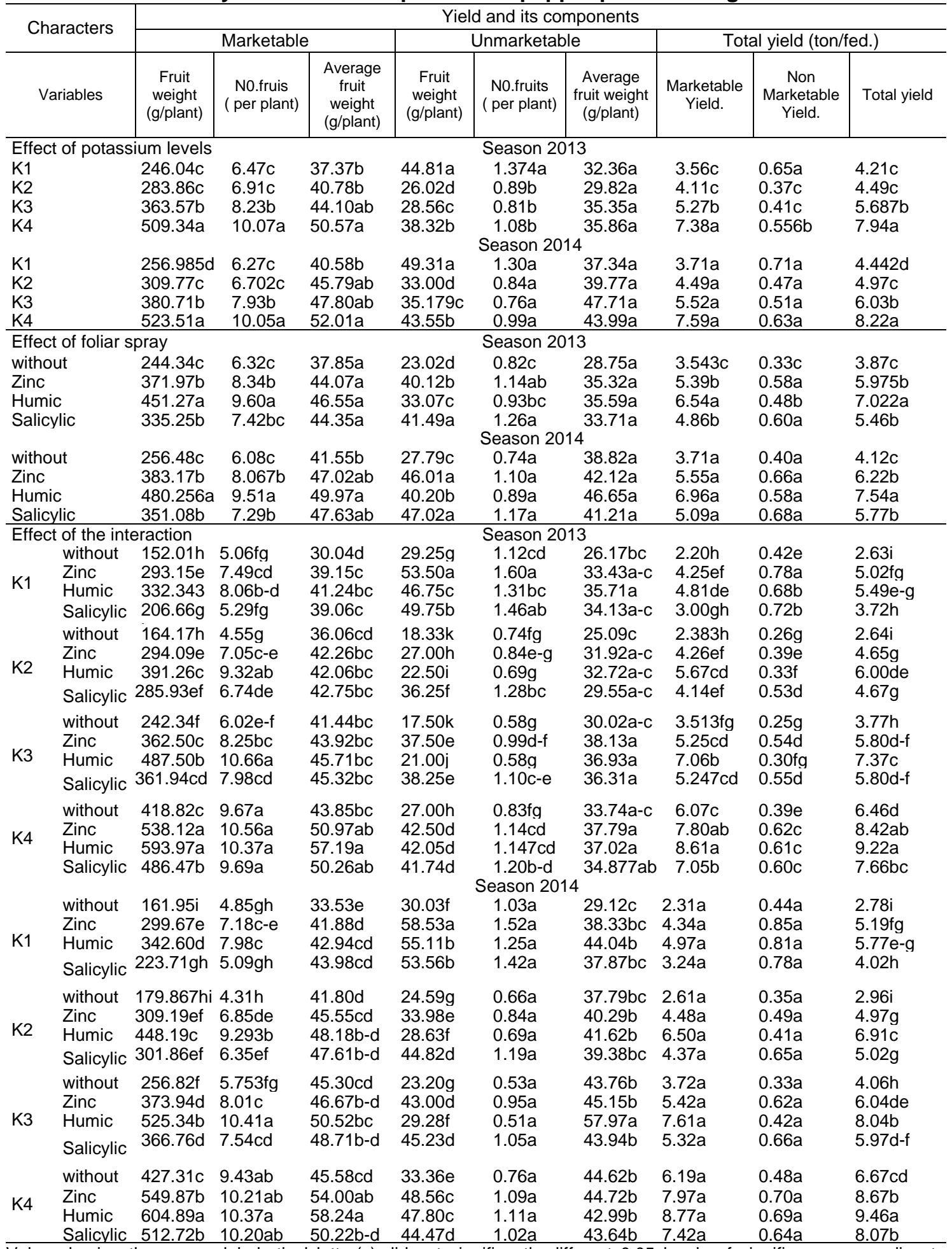

Values having the same alphabetical letter(s) did not significantly differ at 0.05 levels of significance, according to Duncan's multiple range test.

$\mathrm{K} 1, \mathrm{~K} 2, \mathrm{~K} 3$ and K4; Rates of potassium fertilization as follows: 200, 250, 300, and 350Kg per fed. Respectively. Application of foliar spray, i.e. Without spray, Zinc, Humic acid,and Salicylic acid., The spraying rates were as follows, $0.0,1.0 \mathrm{~g} / \mathrm{l}^{-1}, 5.0 \mathrm{~cm} / \mathrm{l}^{-1}$, and $0.5 \mathrm{~g} / \mathrm{I}^{-1}$, Respectively. 
Table 5: Effect of potassium fertilizer levels and foliar spray with some anti- salinity treatments on $\mathrm{N}, \mathrm{P}, \mathrm{K}, \mathrm{Na}$ and proline in the leaves and fruits of pepper plants during 2013-2014 seasons.

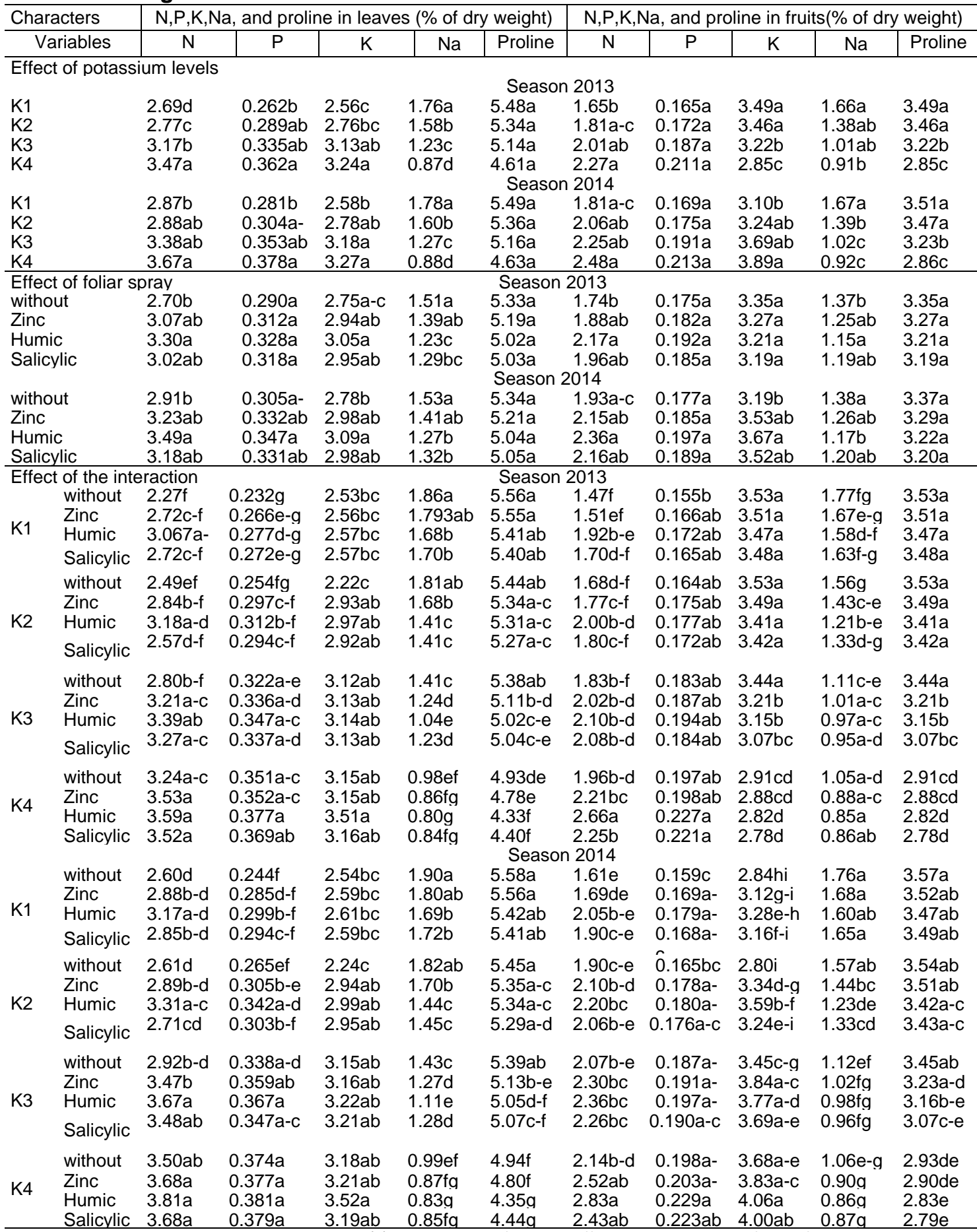

Values having the same alphabetical letter(s) did not significantly differ at 0.05 levels of significance, according to Duncan's multiple range test.

$\mathrm{K} 1, \mathrm{~K} 2, \mathrm{~K} 3$ and K4; Rates of potassium fertilization as follows: 200, 250, 300, and 350Kg per fed. Respectively. Application of foliar spray, i.e. Without spray, Zinc, Humic acid,and Salicylic acid., The spraying rates were as follows, $0.0,1.0 \mathrm{~g} / \mathrm{l}^{-1}, 5.0 \mathrm{~cm} / \mathrm{l}^{-1}$, and $0.5 \mathrm{~g} / \mathrm{I}^{-1}$, Respectively. 
proline content in both leaves and fruits of pepper plants compared to application potassium levels at $(\mathrm{K} 3, \mathrm{~K} 2$ and $\mathrm{K} 1)$, respectively, in both seasons. These results are in agreement with previous investigations indicated by Zhang et al. (2002), and Lin Duo and Danfeng (2003) they found that increment in vegetative growth, net photosynthetic rate; NPK content and chlorophyll content were associated with enhancement of $\mathrm{K}$ levels. Rubio et al. (2003) found that increase in the external $\mathrm{K}$ concentration, from 0.1 to $1 \mathrm{mM}$, reduced $\mathrm{Na}$ uptake by $25 \%$ and a further increase to $10 \mathrm{mM} \mathrm{K}$ reduced the rate of $\mathrm{Na}$ uptake by $44 \%$ with regard to the $1 \mathrm{mM} \mathrm{K}$ treatment. Sarrwy et al. (2010) found that foliar application of $\mathrm{K}$, improved the chlorophyll and fruits NK contents.

\subsection{Effect of foliar spray with anti- salinity treatments}

Data in Table (5) show significant effects of the foliar spray treatments on most studied traits in both seasons, except, proline content in the leaves and $\mathrm{P}$ content in the fruits in both seasons, $K$ in leaves and fruits in the first season. Foliar spray with Humic acid at the $5 \mathrm{~cm} / \mathrm{I}^{-1}$ recorded the highest values of $\mathrm{N}, \mathrm{P}$ and $\mathrm{K}$ content in the leaves and fruits in the both seasons, concerning the contents of $\mathrm{Na}^{+}$and proline in the leaves and fruits; it was found that the highest values were recorded with the control treatment in both seasons. These results are in harmony with those reported by Ayas and Gulser, (2005), they reported that the application of Humic acid was the main cause for enhanced nitrogen uptake in spinach plants. Ameri and Tehranifar (2012) found that the application of humic acid was significantly affected on nutrient uptake of $\mathrm{N}$, $\mathrm{P}$, and $\mathrm{K}$ for Fragaria ananassa plants.

\subsection{Effect of the interaction between potassium levels and foliar spray with anti-salinity treatments}

Data presented in Table (5) show significant effects of the interactions between the application of potassium levels and foliar spray treatments on contents of $\mathrm{N}$, $\mathrm{P}, \mathrm{K}$ and $\mathrm{Na}$ as well as proline in the leaves and fruits of sweet pepper plants. Application of potassium level (K4) with foliar spray by Humic acid recorded the highest values for content of $\mathrm{N}$ and $\mathrm{P}$ in the both seasons, and the content of $\mathrm{K}$ in the leaves in both seasons and fruit in the second season. Also, Addition of potassium level (K4) with foliar spray by any of salicylic acid, Humic acid and $\mathrm{Zn}$ respectively gave the low contents of $\mathrm{Na}^{+}$and proline in the leaves and fruits in both seasons. In support of these findings, Kazemi (2013) found that foliar spray by Humic acid and potassium nitrate $(40 \mathrm{ppm}+100 \mathrm{mg} / \mathrm{L})$ alone or in combinations affected significantly on the content of $\mathrm{N}$ and $\mathrm{K}$ of cucumber plant leaves.

\section{Fruit quality}

\subsection{Effect of potassium fertilization levels}

Data in Table (6) show significant effect of potassium fertilization levels on quality traits of sweet pepper fruits. The highest values of all studied traits i.e. T.S.S, V. C and $\mathrm{pH}$ of fruit juice were recorded with application of high potassium rates; viz, K2, $\mathrm{K} 3$ and K4 without significant differences among them, where the lowest values of previous characters were with the low rate of potassium(K1) In this respect Marschner (1995) reported that the optimum potassium supply determines fruit quality viz, T.S.S, titratable acidity, V. C and $\mathrm{pH}$ of juice of tomato fruits in relation to addition of potassium levels. Increasing potassium fertilizer levels in the nutrient solution confirm that $\mathrm{K}$ played an important role in the configuration of quality profile in tomato fruits. Potassium is the most abundant cation present in the phloem sap (almost $80 \%$ of the total cations) as a consequence of sugar charging and transport mechanisms processes through the phloem into sink 
Table 6: Effect of potassium fertilizer levels and foliar spray with some anti-salinity treatments on $\mathrm{pH}$, vitamin $\mathrm{C}$ and total soluble solids in fruits of pepper plants during 2013-2014 seasons.

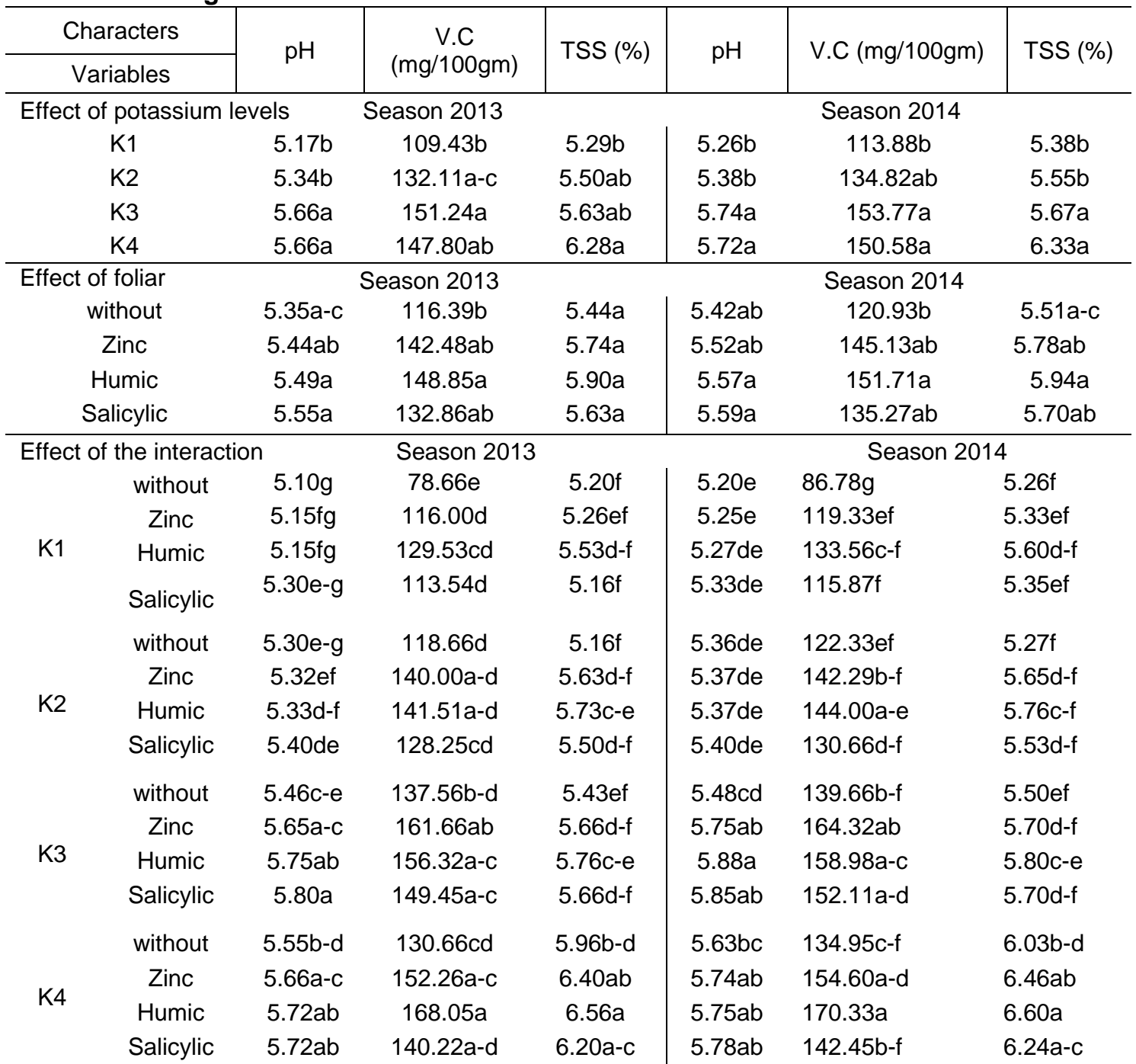

Values having the same alphabetical letter(s) did not significantly differ at 0.05 levels of significance, according to Duncan's multiple range test.

K1,K2,K3 and K4; Rates of potassium fertilization as follows: 200, 250, 300, and 350Kg per fed. Respectively. Application of foliar spray, i.e. Without spray, Zinc, Humic acid, and Salicylic acid., The spraying rates were as follows, $0.0,1.0 \mathrm{~g} / \mathrm{I}^{-1}, 5.0 \mathrm{~cm} / \mathrm{I}^{-1}$, and $0.5 \mathrm{~g} / \mathrm{I}^{-1}$,Respectively.

organs Cakmak (2005). It is known that potassium plays a key role in carbohydrate metabolism and photosynthesis. Balibrea et. al. (2006) on tomato reported that the content of T.S.S increased with increasing potassium levels in the nutrient solution. ElNemr (2012) on tomato found that the contents of T.S.S and $\mathrm{pH}$ in fruit juice were influenced by $K$ levels in the nutrient solution.

\subsection{Effect of foliar spray with anti- salinity treatments}

Data presented in Table (6) show significant effect of foliar spray with Zn, Humic acid and Salicylic acid on all fruit quality traits of sweet pepper fruits. The three spraying treatments; viz, Zinc, Humic acid and Salicylic acid resulted in higher values of all studied traits i.e. T.S.S, V. C and $\mathrm{pH}$ of fruit juice compared with the 
control treatment without significant differences among the three spraying treatments. Soheila (2014) on tomato found that humic acid as foliar application had a significant effect on fruit firmness, T.S.S, vitamin $\mathrm{C}$ content, and total phenol content.

\subsection{Effect of the interactions between potassium levels and foliar spray with anti-salinity treatments}

Table (6) show significant effect of the interactions between application of potassium levels and foliar spray with $\mathrm{Zn}$, Humic acid and Salicylic acid on fruit quality traits. The application of K4 or K3 with spraying by Zinc, Humic and Salicylic acid were the best treatments for all studied traits. Fawzy et al. (2005) on sweet pepper plants, found that adequate of $\mathrm{K}$ nutrition associated with increased in the contents of soluble solids and ascorbic acid. They added also that, application of potassium improved fruit color, and increased shelf life in fruits.

\section{Conclusion and recommendations}

It is obvious from the obtained results that, fertilization of pepper plants grown in sandy soil during the summer season under drip irrigation using saline water (Ec 8.22 ds $\mathrm{m}^{-1}$ ) with potassium sulphat $(350 \mathrm{Kg} / \mathrm{fed}$.) and spraying the plants with Humic acid at $\left(5 \mathrm{~cm} / 1^{-1}\right)$, or salicylic acid $\left(0.5 \mathrm{~g} / 1^{-1}\right)$ or $\mathrm{Zn}$ $\left(1 \mathrm{~g} / 1^{-1}\right)$, respectively produced highest marketable fruit yield with best quality comparing to the control or the other treatments as well as the lowest contents from sodium and proline in the pepper leaves or fruits under the conditions of ElArish, North Sinai were obtained by the previous treatments.

\section{REFERENCES}

Abd El-Rheem, Kh., M. A. A. Afifi and R. A. Youssef (2012). Effect of humic acid isolated by IHSS-N2 / Mn method and P fertilization on yield of pepper plants. life Sci. J. 9 (2): 356-362.
Ameri, A. and A. Tehranifar (2012). Effect of humic acid on nutrient uptake and physiological characteristic Fragaria ananassa var: Camarosa. J Biol. Environ. Sci., 6:77-79.

Andreini, C., L. Banci, L. Bertini and R. Antonio (2006). Zinc through the Three Domains of Life, J. Proteome Res. 5: 3173-3178

A.O.A.C. (1990). Official Methods of Analysis. 15th ed. Pp. 123-126. Association of Offficial Analytical Chemists, Washington DC. U.S.A.

Ayas, H., F. Gulser (2005). The effects of sulfur and humic acid on yield components and macronutrient contents of spinach. J. Biol. Sci., 5(6): 801-804

Balibrea, M.A., C. Martínez-Andújar, J. Cuartero, M.C. Bolarín and F. PérezAlfocea (2006). The high fruit soluble sugar content in wild Lycopersicon species and their hybrids with cultivars depends on sucrose import during ripening rather than on sucrose metabolism. Funct. Plant Biol., 33: 279288.

Bates, L.S., A. P. Waldren and I. D. Teare (1973). Rapid determination of free proline for water-stress studies.Plant and Soil 39:205-207.

Bhuvaneswari, G., R. Sivaranjani, S. Reeth and K. Ramakrishnan (2013). Application of nitrogen and potassium efficiency on the growth and yield of chilli Capsicum annuum L. Int.J.Curr.Microbiol.App.Sci., 2 (12): 329-337.

Bojórquez-Quinta, J. E., I. EchevarríaMachado, F. Medina-Lara and $M$. Martínez- Estévez (2012). Plant schallengesina salinized world: the case of Capsicum. Afr. J. Biotechnol. 11: 13614-13626.doi:10.5897/AJB12.2145

Bremner, J.M. and C.S. Mulvaney (1982). Total nitrogen. P.595-624. In. A.L. page (ed.), methods of soil analysis. Agron. No.9, part 2: chemical and microbiological properties 2nd ed., AM. Soc. Agron., Madison, WI. USA. 
Cakmak, I. (2005). The role of potassium in alleviating detrimental effects of abiotic stresses in plants. J. Plant Nutr. Soil Sci., 168: 521-530.

Canellas, L.P., F.L. Olivares, A.L. FacanhaOkorokova and A.R. Facanha (2002). Humic acids isolated from earthworm compost enhance root elongation, lateral root emergence, and plasma membrane $\mathrm{H}+-$ ATPase activity in maize roorts, Plant Physio. 30: 1951-1957.

Cheny, D.E., M. Nobili and A. Viad (2004). Stimulatory effects of humic substances on plant growth. In: Soil organic matter in sustainable agriculture (Magdoff F., Weil R.R., eds). CRC Press, NY, USA. pp. 103-129.

Duncan, D.B. (1958). Multiple range and multiple $F$ test. Biometrics., 11:1-42.

El-Bassiony, A.M., Z.F. Fawzy, E.H. Abd ElSamad and G.S. Riad (2010). Growth, yield and fruit quality of Sweet Pepper plants (Capsicum annuum L.) as affected by potassium fertilization .J. Ameri. Sci., 6: (12)

El-Nemr, M.A., M.M.H. Abd El-Baky, S.R. Salman and W.A. El-Tohamy (2012). Effect of different potassium levels on the growth, yield and quality of tomato grown In sand-Ponic culture australi. J. of Basic and Appli. Sci., 6 :(3)., 779-784

Fahram, M., M. Hossein, N. Mohsen, S. Alireza, A. Mohammad, A. Shila and R. Khashayar (2014). Influence of humic acid on increase yield of plants and soil properties International Journal of Farming and Allied Sciences Intl J Farm and Alli Sci.Vol., 3 (3): 339-341.

FAO, FAOSTAT, FAO of the UN, Accessed on February4. 2016. http:// faostat.fao.org/site/612/default.aspx \#ancor

Faquin, V. (1994). Mineral nutrition of plants. Lavras: ESAL-FAEPE: p. 227.

Fatma, A. G. (2006). Effect of salicylic acid on the growth, metabolic activities and oil content of basil and majoram. Intl. J. Agri. Biol. 2006; 8(4):485-492.

Fawzy, Z. F., A. G. Behairy and S. A. Shehata (2005). Effect of potassium fertilizer on growth and yield of sweet pepper plants (Capsicum annuum L.) Egypt. J. Agric. Res. 2(2): 599-610.

Fu Jiu, C., Y. Dao Qi and W. Quing Sheng (1995). Physiological effects of humic acid on drought resistance of wheat (in Chinese), Yingyong Shengtai Xuebao. 6: 363-367.

Gonza'lez-Guerrero, M., C. Azco'n-Aguilar, M. Mooney, A. Valderas, CW. MacDiarmid, D.J. Eide and N. Ferrol (2005). Characterization of a Glomus intraradices gene encoding a putative $\mathrm{Zn}$ transporter of the cation diffusion facilitator family. Fungal Genet. Biol. 42, 130-140.

Hsiao, C. and A. Luchli (1986). Role of potassium in plant-water relation. In: Advances in plant nutrition 2nd ed., pp. 281- 312., Tinker and A. Luchli (eds.). Praeger, New York.

Irri, A. (1976). Laboratory manual for physiological studies on Rice. 3rd ed.(Souchi Youshidu D.A frono. J.H. Cook.; and K.A. Gomezeds.) 17-23 The International Ricde Reser. Instit., Los Banos Phillipines.

Jaleel, C.A., B. Sankar, P.V. Murali, M. Gomathinayagam, G.M.A. Lakshmananm and R. Panneerselvam (2008). Water deficit stress effects on reactive oxygen metabolism in Catharanthus Roseus; Impacts on Ajmalicine Accu mulation. Colloids and Surfaces B: Biointerfaces. 62:105111. http://dx.doi.org/10.1016/j.colsurfb.2 007.09.026

Karakurt, Y., H. Unlu and U. Padem (2009). The influence of foliar and soil fertilization of humic acid on yield and quality of pepper. Acta Agr Scand B-P 59:233-237.

Kazemi, M. (2013). Effect of foliar application of humic acid and potassium nitrate on cucumber growth bull. Env. Pharmacol. Life Sci. 2 (11) 3-6

Lin Duo. and H. Danfeng (2003). Effects of potassium levels on photosynthesis and fruit quality of muskmelon in culture medium. Acta Hortic. Sinic., 30 (2): 221223.

Marco, A., L. Huez, L. April, S. Zohrab, P. Geno and P. Robert (2011). Response of 
chile pepper (Capsicum annuum L.) to salt stress and organic and inorganic nitrogen sources: III. Ion uptake and translocation Tropical and Subtropical Agroecosystems, 14 (2011): 765-776.

Marschner, H. (1995). Mineral nutrition of higher plants (Academic Press, San Diego, CA), 2nd ed, 299-312.

Munns, R. and M. Tester (2008). Mechanisms of salinity tolerance. Annu. Rev. Plant Biol. 59: 651-681

Muthulakshmi, S. and K. Lingakumar (2017). Role of salicylic acid (SA) in plants A review International Journal of Applied Research. 3(3): 33-37

Nardi, S., D Pizzeghello, A. Muscolo and A Vianello (2002). Physiological effects of humic substances on higher plants $\mathrm{T}$. Soil Biol. Biochem. 34: 1527-1536.

Navarro, J.M., C. Garrido, M. Carvajal and V. Martinez (2002). Yield and fruit quality of pepper plants under sulphate and chloride salinity. The J. Horti. Sci.; Biotechnol. 77: 52-57.

Padem, H. and A. Ocal (1999). Effects of humic acid applications on yield and some characteristics of processing tomato. Acta Hort., 487: 159-164.

Rubio, F., P. Flores, J.M. Navarro and V. Martínez (2003). Effects of $\mathrm{Ca} 2+, \mathrm{K}+$ and c GMP on $\mathrm{Na}+$ uptake in pepper plants. Plant Sci. 165, 1043-1049.doi: 10.1016/S0 168-9452 (03) 00297-8

Ryan, J.S., Garabet, A. Rashid and M. ElGarous (1999). Assessment of Soil and Plant Analysis. Laboratories in the West Asia North African region. Commun. Soil Sci. Plant Analysis 30: 885-894.

Sarrwy, S.M.A., A Enas.; H.S.A.; Hassan (2010). Effect of foliar spray with potassium nitrate and mono-potassium phosphate on leaf mineral contents, fruit set, yield and fruit quality of Picual olive trees grown under sandy soil conditions. AmericEurasian J. Agric.; Environ. Sci., 8 (4): 420-430.

Sawan, Z.M., S.A. Hafez and A.E. Basyony (2001). Effect of nitrogen and zinc fertilization and plant growth retardants on cotton seed, protein, oil yields, and oil properties. JAOCS, 78 (11): 1087-1092.

Shabala, S. and L. Pottosin (2014). Regulation of potassium transport in plants under hostile conditions: implications for abiotic and biotic stress tolerance. Physiologia Plantarum 151, 257-279.

Snedecor, G.W. and W.G. Cochran (1980). Statistical Methods 7th ed. Iowa State Univ., Press. Ames. Iowa, USA.

Soheila, K., Shahmaleki (2014). Acid humic foliar application affects fruit quality characteristics of tomato (Lycopersicon esculentum cv. Izabella) Agric. sci. dev., 3: (10), 312-316

Sparky, F. (2006). Sparky Boy Enterprises. Planet Natural, 1-6.

Tester, M. and R. Davenport (2003). Na+ tolerance and $\mathrm{Na}+$ transport in higher Plan. Ann. Bot. 91:503-527.

Tisdale, SL., W.L. Nelson and J.D. Beaten (1984). Zinc in soil fertility and fertilizers. fourthedition, macmillan publishing company, New York. pp382-391.

Varanini, Z.; and R. Pinton. 2001. Direct versus indirect effects of soil humic substances on plant growth and nutrition. In: The rhizosphere: biochemistry and organic substances at the soil-plant interface (Pinton R., Varanini Z., Nannipieri P., eds). Marcel Dekker Inc, NY, USA. pp. 141-157.

Wu, H., L. Shabala, K. Barry, M. Zhou and S. Shabala (2013). Ability of leaf mesophyll to retain potassium correlates with salinity tolerance in wheat and barley. Physiol. Plant. 149:515-527. doi: 10.1111/pp I.12056.

Zaky, M.H., O.A.H. El-Zeiny and M.E. Ahmed (2006). Effects of humic acid on growth and productivity of bean plants grown under plastic low tunnels and open field. Egypt. J. Appl. Sci., 21(4B): 582596.

Zhang, A., F. Huang Dan and Z. Hou (2002). Effect of potassium nutrient on development and photosynthesis of melon plant. J.;Shang.; Agric. Colle., 20(1): 13-17. 


\title{
تأثير مستويات من البوتاسيوم وبعض المواد المضاده للملوحهه على الفلقل الحلو النامى

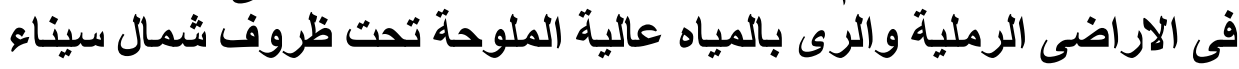

\author{
سامح عبا الحفيظ علي أبوالقاسم

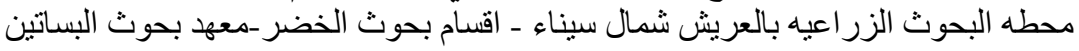 \\ - مركز البحوث الزر اعبة_الجيزة-مصر.
}

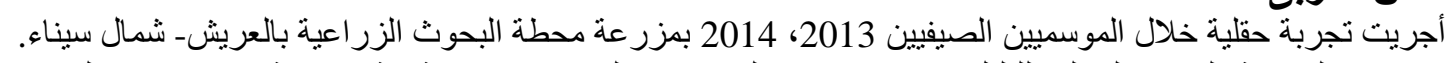

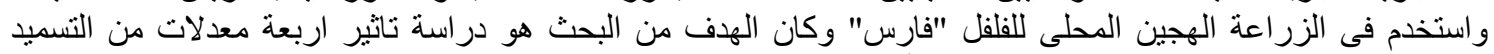

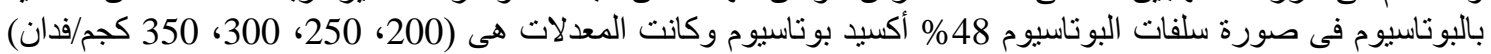

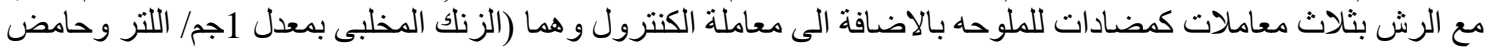

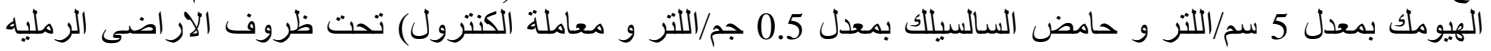

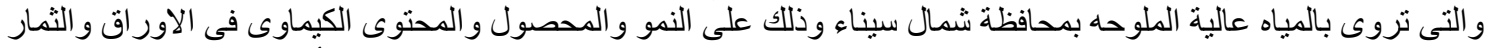

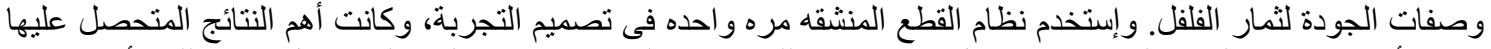

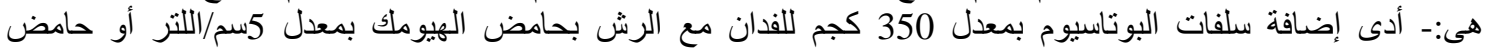

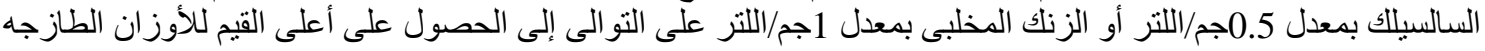

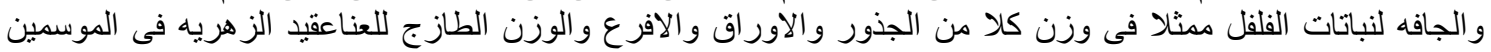

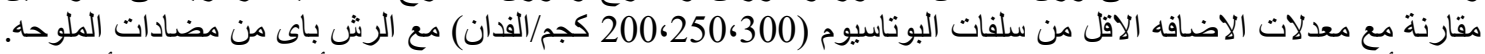

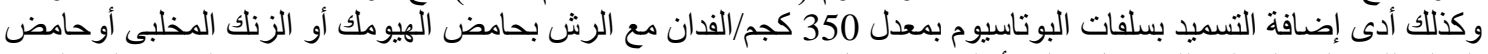

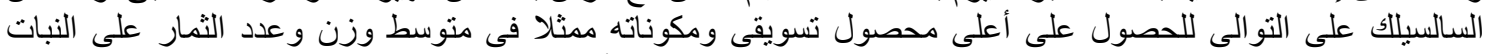

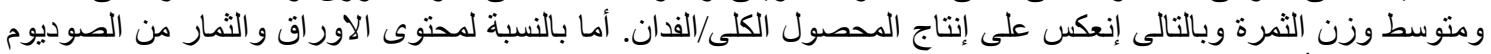

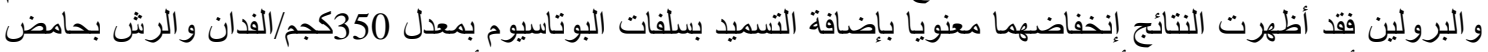

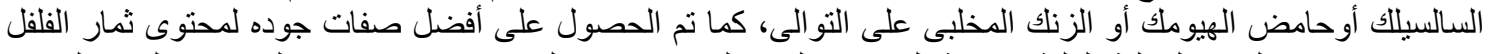

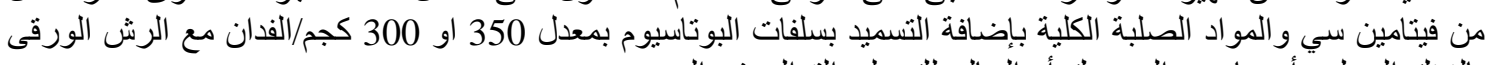
بالزنك المخلبى أو حامض الهيو ميك أو السالسيلك على التو الى فى الموسمين. 